Man and Nature

L'homme et la nature

\title{
The Rhetoric of Grace in Jonathan Edwards' Personal Narrative
}

\section{John Stephen Martin}

Volume 4, 1985

URI : https://id.erudit.org/iderudit/1011839ar

DOI : https://doi.org/10.7202/1011839ar

Aller au sommaire du numéro

Éditeur(s)

Canadian Society for Eighteenth-Century Studies / Société canadienne d'étude du dix-huitième siècle

ISSN

0824-3298 (imprimé)

1927-8810 (numérique)

Découvrir la revue

Citer cet article

Martin, J. S. (1985). The Rhetoric of Grace in Jonathan Edwards' Personal Narrative. Man and Nature / L'homme et la nature, 4, 109-127.

https://doi.org/10.7202/1011839ar

Copyright (C) Canadian Society for Eighteenth-Century Studies / Sociéte canadienne d'étude du dix-huitième siècle, 1985
Ce document est protégé par la loi sur le droit d'auteur. L'utilisation des services d'Érudit (y compris la reproduction) est assujettie à sa politique d'utilisation que vous pouvez consulter en ligne.

https://apropos.erudit.org/fr/usagers/politique-dutilisation/ 


\section{The Rhetoric of Grace in Jonathan Edwards' Personal Narrative}

In the years between 1734 and 1742, Americans of the eastern provinces experienced a so-called 'Great Awakening' of religious piety. ${ }^{1}$ One of the features of this 'Great Awakening' was the attempt to render in words the actual moment of grace experienced by the individual. An earlier generation could point to an episode and note that one's beliefs about oneself and God were suddenly transformed by remorse and a desire for penance, and that eventually one received an understanding of right religious doctrines. But memoirists in the eighteenth-century, influenced by the Enlightenment, were hard pressed to account for grace within the concept of phenomenal experience. The problem appeared to be primarily theological but it was also a matter of language: that is, how could one document a spiritual change of one's being when the language of documentation seemingly referred only to the ideas of the mind and not to the substance of things or to God's being?

Historians of religion in America are aware of the breakdown of Puritan piety in seventeenth-century New England, when the children of the first-generation settlers were no longer confident of ascertaining a 'regeneration' of their spiritual being; and these historians can point to the influence of the Enlightenment from Europe - primarily in the form of Locke's concepts of experience and sensationalism - which gave support to Deist and Arminian revisions, both of which challenged the 'covenant' Calvinism of New England and made moral conformity a credible, rational substitute for the indefiniteness of spiritual piety. ${ }^{2}$ To 
be sure, intellectual historians can depict the process of 'regeneration' in the period of the 'Great Awakening,' referring to the changing theory of mind at that time, but only briefly do they delve into the importance that eighteenth-century men attached to the verbal documentation of their 'regeneration,' and particularly to the rhetoric of that documentation. Their rhetoric permitted these men to use 'experiential' words to express how Providence intervened into their lives with truths that were supernatural. It is this aspect of rhetoric that is investigated here.

Again, the religious studies of intellectual historians, in contrast to this one, center on the comparison of religious ideas, doctrines, and practices as well as tracing influences and defining the controversies of the day. They are useful here because they do note the importance of the rise of Antinomianism and Arminianism in transforming church doctrine and practices in eighteenth-century New England. Antinomians had always argued that grace 'regenerated' the individual so that God henceforth acted through the 'saved' individual, and this man need no longer question whether his thoughts and actions were right or wrong. In effect, this immediate 'sanctification' meant that the 'saint' could interpret Scripture directly, and thereby the 'saint' transcended all worldly experience and institutions. Indeed, since 'regeneration' was God's gift of an 'instantaneous change' in a man's nature, it did not depend upon an individual's receiving instruction in church doctrine as preparation for reading Scripture, and this new self-reliance did away with the need for a learned ministry.

The Arminians of the eighteenth-century, on the other hand, were often rationalists, deists, or dissenting evangelicals who believed that man had an ability to effect his own salvation either by entertaining right doctrine, practicing virtue, or enunciating pious thoughts. In effect, God granted grace because men prepared themselves to receive it. Arminians not only challenged anew the Calvinist's doctrine of Election, but as did the Antinomians, they also challenged the ministers who controlled 'the keys of the kingdom,' since ministers had authority to determine who could understand and properly articulate the logos of Scripture upon which church doctrine rested. ${ }^{3}$

But a look at the life and work of one man shows the limits of this approach of intellectual historians. Jonathan Edwards was one theologianpreacher of the 'Great Awakening' who sought to answer the nonorthodox challenges, especially that of the Arminians who had the 'new science' of Locke and Newton on their side. However, Edwards is a paradoxical figure: he is the 'greatest' single figure of the 'Awakening,' but also the 'least typical,' for he was a student of the 'new science' at the same time that he held that reason and experience were 'worthless' 
without the action of a divine light which creates a 'new sense' of the world within the individual. ${ }^{4}$ Indeed, Edwards' treatment of the ideas of Locke and Newton is so complex, and possibly contradictory, that commentators tend to view Edwards as either going beyond his 'sources' or rejecting them outright. Perry Miller, for one, saw Edwards as conjoining Scripture, nature, history, and mind into one new rationalistic 'revelation' of truth in the world, and considered this new coherence as Edwards' redefinition of Locke's understanding of 'experience. ${ }^{\prime 5}$ In response to Miller, Vincent Tomas and Peter Gay found that Edwards, despite his awareness of Newton and Locke, was a 'medieval philosopher' because Edwards followed Scripture, not experience, to define his truths, and he used the ideas and rhetoric of Locke and Newton to confirm his religious convictions. ${ }^{6}$ These rebuttals to Miller's view were often as monolithic as was Miller's original assessment. But more recent scholarship has shown that Edwards derived many of his views of the 'new science' indirectly from moral naturalists such as Nicholas Malebranche, Samuel Clarke, and William Wollaston. ${ }^{7}$ Further, in a major analysis, Wallace Anderson has argued that there is inconclusive evidence that Edwards as a student at Yale read Locke, and it can be shown that Newtonian influence upon Edwards' early writings was minimal; it would appear that Edwards developed his major ideas on his own or from other sources, and only turned to Locke and Newton to 'use' them. ${ }^{8}$ In the end, despite these possible influences, it would appear that Edwards was primarily indebted to the traditions of 'covenant' Calvinism in a way that church historiography has not yet fully clarified. ${ }^{9}$

Although there is no consensus as to the influences upon Edwards, it is clear that Edwards' interpretation of the ideas of Locke and Newton, particularly in regard to notions of sensationalism and phenomenal experience, has had immense implications for his theology and his attack on Antinomianism and Arminianism. This can be seen in the way that Edwards attempted to define the experience of grace.

In the prior century, grace was assumed to act directly upon the mind which then had an intellectual awareness of 'right doctrine' that would, with training, be able to elucidate Scripture as the direct Revelation of God's will. Only the Elect could receive grace, but the ministry had to test those persons who presented themselves as the Elect within the theocracy of New England. The theory was that the text of Scripture would be meaningless to a person without grace, even if he knew church doctrine. But in fact, a man who was not able to use language figuratively to conjoin word and doctrine with rhetorical emphasis would not be able to sustain an exegesis of Scripture. ${ }^{10}$

The problem of being able or not 'to read' Scripture was subjected to 
empirical analysis in the eighteenth century. For Edwards, as for many others, the problem was to show how words applied to the Bible were as valid as words applied to phenomenal experience. Perry Miller has argued that Edwards believed, as Locke did, in a nominalist theory of words - that a word is an idea separable from reality or the thing which gives rise to phenomenal sensations. As discussed earlier, this may or may not be accurate; but interestingly, because of this belief, Miller can argue that Edwards went beyond Locke's analysis by insisting that an idea could be comprehended emotionally as well as intellectually, and this emotional 'affection' is a 'unit of experience' that is as sensibly apprehended as a colour or the shape of a physical object might be. Thus, Miller concludes, grace for Edwards is a 'new simple idea' that is as valid as a simple idea derived solely from physical sensations. ${ }^{11}$ Miller's view seemingly indicates Edwards' intent of making grace valid and credible in an age of reason.

But a distinction might be made here: more important than making grace experiential, Edwards wanted to 'prove' the supernaturalness of grace. This supernaturalness of grace stands behind Edwards' use of the terms 'well disposed' and 'inclined' in his dissertation on The Freedom of the Will to indicate that although God controlled the phenomenal makeup of experience, and a man could not choose to see or not to see what God presented, yet a man could agree to God's will, as it existed prior to experience, if he had the grace to be so inclined or well disposed. ${ }^{22}$ In effect, the 'disposition' - implanted by God, but choosing freely thereafter - gave an empirical grounding to the medieval Calvinism of the predestined will (and possibly misled Miller). But the concept of the disposition was primarily a means to explain why some people could not believe doctrines even if they had the phenomenal 'affections' of piety. ${ }^{13}$ An individual who was not 'disposed' could not receive supernatural grace, and this inability would be known to himself and others because after the subsiding of his 'affections,' to use Miller's paradigm, he had no lasting 'simple idea' of 'right doctrine' in his mind. ${ }^{14}$ Thus, Edwards conceived that he was defending the orthodox notion of God's Election by predetermined grace, but even so, his defence required a new rhetoric to describe it. Specifically, if grace was a 'simple idea' that might come from divinely appointed 'affections,' the authentic supernatural had to be distinguished from a mere phenomenal chimera. This is clear, for despite the apparent emphasis on grace as a 'simple idea,' Edwards used the same test of Scripture as did his predecessors; that is, the 'new sense' in 'saints' had to generate spiritual knowledge whenever it encountered Scripture. ${ }^{15}$

The meaning of grace for Edwards, I suggest, is evidenced as much by the rhetorical structure of his personal memoir of 'regeneration' as it is in 
any of his argumentative treatises. To see this in the rhetoric of Edwards' memoir, let me turn first to the autobiographical memoir of Thomas Shepard, a clergyman of the first generation to settle in New England. Shepard's memoir is not troubled by theorizings about phenomenal experience and thus does not note sensations or the sequence of feeling and intellectual awareness; instead, the strategy of Shepard's memoir is to systematize his experience rhetorically so that the rhetoric suggests what happens to him, and what he cannot describe experientially. He first notes a period of instruction in the Bible while attending Cambridge, and then depicts how he flew away from such instruction to partake of riotous living, as if the truth of the Bible conflicted with his own willfulness. Finally, after one night of dissipation (that immediately followed a period of prayer), Shepard found himself waking late on a Sunday, and in self-disgust, took himself to a cornfield. Here it was that Shepard had his 'regeneration,' and moved from self-disgust to remorse and finally to penitence. This is what he says of his 'turn of heart':

And when I awakened I went ... in shame and confusion, and went out into the fields and there spent the Sabbath lying hid in the cornfields where the Lord, who might justly have cut me off in the midst of my sin, did meet me with much sadness of heart and troubled my soul for this and other my sins which then I had cause and leisure to think of. And now when I was worst he began to be best unto me and made me resolve to set upon a course of daily meditation about the evil of sin and my own ways. Yet although I was troubled for this sin, I did not know my sinful nature all this while. ${ }^{16}$

Implicit here is a meeting with God the father, but there is no question that God did not physically appear; what makes the meeting 'work' rhetorically is that God must have mourned for Shepard because Shepard himself experienced remorse, and this remorse implied that God had 'turned' Shepard's heart and had given him a way for penitence ('a course of daily meditation'). Moreover, the last line, which contrasts a new view of himself to the old, is an implicit testimony of a 'new sense' that appeared without notice, and thus indicated or betokened a charismatic experience which must be that of grace. This last line is the key one, for it echoes and emphasizes that God had 'accepted' him and considered him worthy of 'justification' through the gift of free grace.

To be sure, the process of salvation did not end with the experience in the cornfield that 'justified' Shepard in the eyes of God. The experience in the cornfield was only the preparatory part of a larger process. The experience had made the date and hour memorable, but this experience of 
grace made him believe that he had the courage to hear God's word in sermons, and to allow the words to be an examination for him:

The Lord therefore sent Doctor Preston to be Master of the College, and ... I began to listen unto what he said, and the first sermon he preached was Romans 12 - to be renewed in the spirit of your mind - in opening which point, viz., the change of heart in a Christian, the Lord so bored my ears as that I understood what he spake and the secrets of my soul were laid upon [i.e. open] before me - the hypocrisy of all my good things I thought I had in me - as if one had told him of all that ever I did, of all the turnings and deceits of my heart ....(41-2)

As a result of these religious practices, Shepard now could feel that any penance for sin would be acceptable to God, since such penance would be a token of his own disposition to follow God's will, rather than be a payment to set himself free of a debt to God, and thenceforth to persist in his own will. This stage was termed 'sanctification,' and its central supporting doctrine was the belief in God's Majesty, because a man henceforth would be doing God's will in all his acts. The chief sign of Shepard's sanctification was his subsequent demonstration to a minister that he could easily receive and understand church doctrine; to do this, Shepard had to relate how such doctrines ultimately derived from the Bible, that is, from the so-called logos that gives God's reasons for sin and redemption, and which St. John says is Christ the mediator made incarnate as man and as doctrine. The Bible, it was thought, sets forth the basis of church doctrine, but it also demands of a believer a disciplined exegesis of God's will for the rationalization of Christ: both aspects doctrinal enunciation and figurative exegesis of Biblical events - make up the logos which instructs man. To be sure, Shepard does not detail his examination in his memoir. However, the process Shepard had worked through had a rhetorical function essential to the seventeenth century definition of grace; it implied that the recorded experience of 'the turn of heart' prepared the soul for the understanding of the logos which is God's own thoughts, and since Shepard himself had become a minister, he could speak of his personal experience with authority even though he did not reveal the examination. Thus, the important point to note here is that Shepard did not need to express grace in phenomenal terms because the rhetorical pattern of the process was completed by his evident response to the logos. In this way, Shepard's memoir was not a mere record but a crafted depiction that served a rhetorical function: by making grace a clear process of 'justification' and subsequent 'sanctification,' the memoir 
validated Shepard's salvation without describing and analyzing the 'turn of heart' in phenomenal terms.

However, the neatness of Shepard's rhetoric did not persist. In the eighteenth century, Americans became conscious of the concepts of reason and phenomenal experience which contrasted with and challenged the narrow theological debate over piety versus moralism. The question became larger, and more philosophical: was grace conveyed to man within phenomenal sensations, so that its appearance followed natural laws that governed all sensational experience? Or, was grace an invisible, ineffable experience, that only the subject could attest to by such signs as his emotional 'affections'? In other words, the philosophical problem was two-sided: Could supernatural grace ever be known phenomenally? And, could an apparently pious man have pleasurable 'affections' following from natural causes, not necessarily connected with grace, and thus delight in a comfortable illusion of his 'justification'?

It is this two-sided problem which the Personal Narrative of Jonathan Edwards addresses. Edwards is best known for his celebrated 1741 sermon entitled 'Sinners in the Hands of an Angry God,' in which he compares man and his wilful works to a spider building a tenuous web over a raging fire. Perry Miller, some twenty-five years ago, wrote that Edwards attempted to compel a 'turn of heart' in his congregation by manipulating the spider image to upset people's complacency. ${ }^{17}$ But Miller also, to avoid contradiction, ignored the fact that Edwards was appalled by the whimperings, faintings, and convulsions he faced, and that he begged the congregation to desist so that he could continue his sermon on the doctrine of God's Majesty. ${ }^{18}$ The point is, Edwards was interested in the role of emotions during the stage when the heart 'turns,' but he was doubtful that such a 'turn' could come from a fanciful analogy of man to a spider: it could only come, as I shall show, from the logos of Scripture, that Edwards, aided by the rhetorical function of a systematized process of salvation, attempts to make phenomenally experiential.

To make this point about the role of emotions clear, the Personal Narrative begins with a notice of how he, as a very young boy, mistook the pleasures of pretentious piety built upon ritual for the presence of supernatural grace. He wrote:

And I am ready to think, many are deceived with such affections, and such a kind of delight, as I then had in religion, and mistake it for grace. (57)

We shall later see that this 'delight' in the emotions haunted Edwards; but here the passage sets Edwards' task to define true piety even though man is tied to the senses of the phenomenal world. Edwards, unlike the non- 
critical Antinomians who presumed that the presence of grace was evidenced by joy and exhilaration, had to demonstrate either that grace was inherent in phenomenal events or else that grace transcended the phenomenal; it did not seem that he could avoid both description and analysis of phenomena as Thomas Shepard had done. The first route would mean that all men could receive grace if they observed the natural, a result which would undermine God's Majesty; and the second approach, of demonstrating transcendent grace, would mean attempting to use a rhetorical strategy to imply what phenomenal words and phrases could not. And this latter is the approach Edwards took.

However, literary historians generally ignore Edwards' rhetorical strategies. Perry Miller explained that Edwards used words - or what we would properly call 'diction,' or word choice - as part of a 'rhetoric of sensation,' because Edwards misread or extended Locke's epistemology and its nominalist theory of words. That is, for Locke, words were nominalist creations which made men mindful that sensations ought to be analyzed and which should point exclusively to sensational referents. Edwards extended this notion, says Miller, so that the reverse was also ideally true: even though the emotional 'affections' and imaginings were responses within the mind to the phenomenal sensations, Edwards considered the 'affections' to be a phenomenal experience that validated the presence of grace, and thus the supernatural actually followed the process of natural laws. ${ }^{19}$ More recent studies have stressed how diction and phrasings allowed Edwards to create a 'conjunction' of phenomenal aspects of the natural world, and conclude that Edwards used the 'esthetic of conjunction' within the natural world to suggest, in turn, the unity of the natural with the supernatural..$^{20}$ Thus, both Miller and later commentators stress diction, not rhetorical strategy, and find good evidence in the following scene, in which Edwards walks one day into the woods and has a direct experience of what appears to be grace:

Not long after .... I gave an account to my father of some things that had passed in my mind. I was pretty much affected by the discourse we had together; and when the discourse was ended, I walked abroad alone, in a solitary place in my father's pasture, for contemplation. And as I was walking there, and looking up on the sky and clouds, there came into my mind so sweet a sense of the glorious majesty and grace of God, that I know not how to express. I seemed to see them both in a sweet conjunction; majesty and meekness joined together; it was a sweet, and gentle, and holy majesty; and also a majestic meekness; an awful sweetness; a high, and great, and holy gentleness.

After this my sense of divine things gradually increased, and became more and more lively, and had more of that inward sweetness. The appearance of every 
thing was altered; there seemed to be, as it were, a calm, sweet cast, or appearance of divine glory, in almost every thing. God's excellency, His wisdom, His purity and love, seemed to appear in every thing: in the sun, moon, and stars; in the clouds, and blue sky; in the grass, flowers, trees; in the water, and all nature; which used greatly to fix my mind. I often used to sit and view the moon for continuance; and in the day spent much time in viewing the clouds and sky to behold the sweet glory of God in these things; in the mean time, singing forth, with a low voice my contemplations of the Creator and Redeemer. And scarce anything, among all the works of nature, was so sweet to me as thunder and lightning; formerly, nothing had been so terrible to me. Before, I used to be uncommonly terrified with thunder, and to be struck with terror when I saw a thunderstorm rising; but now, on the contrary, it rejoiced me. I felt God, so to speak, at the first appearance of a thunderstorm; and used to take the opportunity, at such times, to fix myself in order to view the clouds, and see the lightnings play, and hear the majestic and awful voice of God's thunder, which often-times was exceedingly entertaining, leading me to sweet contemplations of my great and glorious God. While thus engaged, it always seemed natural to me to sing, or chant for my meditations; or, to speak my thoughts in soliloquies with a singing voice. ${ }^{21}$

One can easily allow that Miller and the esthetes of 'conjunction' rightly see this moment as a personal experience of joy confirming the gift of grace. But they overemphasize Edwards' artistic control over metaphor, ignore the role of incantation, and read the passage in a distorting isolation, separate from the full process of salvation which Edwards is at pains to make specific. ${ }^{22}$

From their perspective of artistry, the word 'sweet' implies a metaphor of a bee seeking honey, and this naturalistic seeking of a bee for honey is a vehicle expressing the instinctive hunger of Edwards for God. As a result of this 'hunger,' majesty is conjoined with gentleness, and Edwards is conjoined with God; the resulting harmony may express that a man is justified.'23 But in making this point, commentators pass over Edwards' caution that the metaphor is flawed because it is an imagining rather than a sensational phenomenon and the experience of grace is essentially inexpressible ('I know not how to express'). Thus, as important as the word 'sweet' may be as a 'figure,' it cannot confirm 'regeneration.'

Rather, the process of 'regeneration' depends upon a reversal of how one sees one's self, as Thomas Shepard had clarified. This means that instead of using 'conjunction' to explain 'justification,' 'conjunction' must signal an irrepressible 'turn of the heart' which is virtually destructive of one's old sense of self. To do this, Edwards uses the mode of incantation so that words come forth apparently in haphazard fashion although syn- 
tax suggests coherence for the words. ${ }^{24}$ In the above passage, incantation allows the mind to consider majesty and graciousness as a single idea, and this novelty creates an ineffable emotion that signals a new, persuasive understanding of what hitherto would be a paradox. In this context of incantation, 'sweet' has a decidedly rhetorical function, rather than merely being an artistic 'figure,' because it signals the irony of finding 'sweetness' where one least expects it - in the frightening sensations of a thunderstorm. It is a rhetorical irony that corresponds to Shepard's clear reversal as he saw his sinful status through the eyes of God, a vision of himself which made him aware of his 'regeneration.'

My point is that, in using the word 'sweet' as a rhetorical signal, Edwards draws attention to his 'turn of heart,' and he need not explain his assertion that simultaneously with this change, there was an 'alteration' within nature. This word - 'alteration' - as it remains undescribed and unanalyzed, implies that at the moment, the laws of phenomena were suspended so that everything appeared to be different; either the objects themselves changed or they seemed to change because of the 'new sense' that Edwards henceforth had of them. Thus, Edwards intimates that grace is a supernatural intervention rather than a naturalistic event, and his emotional response is not to be confused with an ordinary emotional response.

My view of Edwards' rhetoric of grace means that this scene is not complete in itself, but must be seen in its relation particularly to the logos and the importance of right doctrine, as part of the entire process of 'regeneration.' Indeed, several paragraphs before, the cycle is noted as beginning sometime about December, 1720, when Edwards, at the age of seventeen, was seized with remorse and suffered a deep illness which might have been psychosomatic. In the light of the traditional rhetoric of grace, Edwards' real 'turn of heart' occurred at this time. Then he tells how he had 'objections' since childhood against the 'horrible' doctrine of God's sovereignty - which is exactly the doctrine celebrated in the thunderstorm scene. Moreover, Edwards at that time is specific about his 'turn of heart' because of a reading of the Bible:

The first instance that I remember of that sort of inward, sweet delight in God and divine things that I have lived much in since, was on reading those words, 1 Timothy 1:17. Now unto the king eternal, immortal, invisible, the only wise God, be honor and glory for ever and ever, Amen. As I read the words, there came into my soul, and was as it were diffused through it, a sense of the glory of the Divine Being; a new sense, quite different from anything I ever experienced before. (59) 
One should note here that Edwards has avoided the need to distinguish the emotions and the 'turn of heart' from the causal remorse because he demonstrates how the logos of Scripture was clear to him. Here the logos has no reference to the real world of phenomena, but points to transcendent beliefs which are believable only within the context of the Bible. However, it is true that the rhetoric of grace makes the logos of the Bible credible if one responds emotionally to the text. This understanding of the logos is emphasized in the very next paragraph when Edwards writes:

And my mind was greatly engaged to spend my time in reading and meditating on Christ, and the beauty and excellency of His person, and the lovely way of salvation, by free grace in Him. I found no books so delightful to me as those that treated of these subjects. Those words of Canticles 2.1, used to be abundantly with me: I am the Rose of Sharon, the lily of the valleys. The words seemed to me, sweetly to represent the loveliness and beauty of Jesus Christ. And the whole book of Canticles used to be pleasant to me .... (60)

Here we have not real flowers used as a metaphor of Christ, but a metaphor within the Bible which alone can represent the supernaturalism of Christ. This passing over real flowers for metaphorical ones is not noticed by Edwards because in Edwards' time the Bible is considered to be God's literal thoughts, and the 'rose' and the 'lily' of Scripture are words as real for the pure spirit that is Christ as phenomenal flowers are real to men. It is the contemplation of the Bible which sees its metaphors as direct signifiers of the supernatural, that expresses for Edwards what is meant by perceiving the logos, the word that is God. Continuing the above passage he notes how in reading the Canticles, he received 'an inward sweetness':

This I know not how to express otherwise, than by a calm, sweet abstraction of soul from all the concerns of this world; and sometimes a kind of vision, or fixed ideas and imaginations, of being alone in the mountains, or some solitary wilderness, far from all mankind, sweetly conversing with Christ, and wrapt and swallowed up in God.

The passage does not define what is meant by the 'kind of vision' that results from the reception of the logos; but the passage 'points' rhetorically to the thunderstorm scene that follows as a 'type,' reflecting the archetype of the logos, and intimates that he could perceive divine 'alterations' within nature. The point, then, is that without the prior experience of the logos of Scripture, giving him a 'vision' of 'fixed ideas and imagina- 
tions,' Edwards would never be able to see the 'alterations' that bespeak a 'new sense' and attest to his 'regeneration'.

These experiences of the logos precede the thunderstorm scene in which Edwards presents a phenomenal experience of 'regeneration.' But the cycle is not yet complete. It is important to note that Edwards completed his conversion only two years later - in January, 1723 - when he made an entry in his diary attesting to his full consciousness of salvation. This final step would correspond to what Thomas Shepard would have been allowed to say to his minister after his examination to see if he could locate and explicate significant doctrines within Scripture. Edwards' statement is not just an avowal - legalistic, as commentators say; it also conveys the doctrine of God's Majesty which was essential earlier, in the thunderstorm:

On January 12, 1722-23 I made a solemn dedication of myself to God, and wrote it down; giving up myself, and all that I had to God; to be for the future, in no respect my own; to act as one that had no right to himself, in any respect. And solemnly vowed to take God for my whole portion and felicity ... and His law for the constant rule of my obedience .... (64)

To be sure, Edwards did not make this statement to a minister. But such is the rhetorical success of his avowal completing the cycle with the central doctrine of God's Majesty, that general readers and commentators alike easily ignore this omission as well as another important feature of the Personal Narrative. That is, Thomas Shepard asserted that his salvation began that day in the cornfield, even though he was subject to 'backsliding' and consequential anxiety. But Edwards evidently had a doubt about the very nature of 'regeneration' because he depicts no less than two experiences of conversion by grace. And the force of the second conversion in the memoir depends upon contrasting the relatively orthodox first one with what appears to be a new process, affecting Edwards' ultimate definition of grace.

Edwards' second experience took place some three years later, in 1725, when he was twenty-two years old. At that time, he was 'perplexed and distracted' from his pursuits after holiness, and again he was ill, perhaps psychosomatically. Again, his anxiety ended only when Edwards read Scripture, but this time, instead of being separated into stages as before, the understanding of the logos seems to occur simultaneously with the phenomenal 'turn of heart' or 'affection' to which he intellectually responds.

I observed that those who watched with me would often be looking out for the 
morning, and seemed to wish for it. Which brought to my mind those words of the Psalmist, which my soul with sweetness made of its own language, My soul waitest for the Lord, more than they that watch for the morning; I say, more than they that watch for the morning; and when the light of the day came in at the windows, it refreshed my soul from one morning to another. It seemed to me to be some image of the light of God's glory. (66)

In this passage it is impossible to separate the 'turn' from the instruction by the logos. But similar to the 'alteration' of nature in the thunderstorm scene, the reading of the Psalm transforms the phenomenal circumstances of his sick room into the exact words of the Psalmist's wish for salvation, and the process of exegesis itself - joining together the 'justified' man to the text that 'sanctifies' - transcends the earlier process of conversion. I have said that the pietists collapsed 'justification' and 'sanctification' into one experience, so that they could directly read Scripture for doctrine. Edwards seemingly would do the same here, but the distinction is that Edwards wants to show that the logos remains the single source of an unmistakable trascendent, supernatural experience. Indeed, in basing his second conversion directly on the words of Scripture and constraining his more personal emotional reactions to conform to these words, Edwards could be assured that this 'turn of heart' was no hallucination - as the thunderstorm scene might have been, and it was also no feverish wish during an illness because true doctrine lifted his depression.

However, this second conversion does not really end at this point. Because of his depiction of the logos transforming phenomenal circumstances, Edwards had prepared the way for receiving transcendent visions as if they were actual experiences. These visions begin in the second half of the Narrative, after Edwards skips from the conversion of 1725 to an occasion in 1737, when he rides out into the woods. This scene should be contrasted with the earlier one of the thunderstorm for its language and its effect. In this later scene he had a direct vision of the person of Christ for about an hour's duration:

... I had a view that for me was extraordinary, of the glory of the Son of God, as Mediator between God and man .... The person of Christ appeared ineffably excellent with an excellency great enough to swallow up all thought and conception ... which continued as near as I can judge, about an hour; which kept me the greater part of the time in a flood of tears, and weeping aloud. (69)

Now Christ, who is the logos incarnate, appears directly within the transience of time and as an 'alteration' within space. The depiction of 
the logos within phenomena marks the ultimate form of the rhetoric of grace: no exegesis is required and no dispute about doctrine is possible. Modern commentators who ignore the rhetorical patterning of 'regeneration' that I have pointed out suffer embarrassment for Edwards' vision of Christ, as if it undermined his theology and showed him to be psychologically unstable. But the patterning gives rhetorical credibility to a transcendent being who exists eternally outside time and space. After this encounter, therefore, Edwards may admit, as he does, that he at 'several other times had views very much of the same nature and that have had the same effects' (66).

Indeed, the vision of the Christ as the logos is the most perfect testimony of salvation, as Edwards sees the God whose Majesty he is so 'well disposed' to accept. But the vision has become more important, one notes, than the 'delight' in the 'affections' which earlier could be confused with merely temporal gratifications associated with false piety.

For this reason, Edwards acknowledges - or rather, confesses - what actually impelled him to undertake his Personal Narrative:

Though it seems to me, that, in some respects, I was a far better Christian, for two or three years after my first conversion, than I am now; and lived in a more constant delight and pleasure; yet, of late years, I have had a more full and constant sense of the absolute sovereignty of God, and a delight in that sovereignty; and have had more of a sense of the glory of Christ, as Mediator revealed in the gospel. (71)

Here, plain enough, is the voice of maturity, aware that if it once was distrustful of the 'delight' of joy as a test of grace, now it would assert that the clarity of the logos gives the confirming 'affection' of 'delight.' And now Scripture is not merely the basis and confirmation of right doctrine, but is foremostly a transcendent experience in which the logos becomes as valid as phenomenal experience is commonly thought to be in the eighteenth-century.

Such is the real thesis of the Personal Narrative, and it is intended to still the anxieties of aging of which Edwards became conscious when he began the memoir about 1740, at the height of the 'Great Awakening.' People were uncritically accepting emotional confirmations, negating entirely the aspect of right doctrine and the test of Scripture. It was true, for Edwards, that right doctrine meant primarily God's Majesty - a quite radical view since most congregations believed their ancestors had made a legal covenant with God to limit His powers and make Him understandable to man. But Edwards did, each time, end with right doctrine and Scripture, to show how traditional he viewed his experience and belief. 
Ultimately, Edwards' unique view of the origins and efficacy of grace would isolate him from the mainstream of religious practices; and this isolation did occur in 1750 when his congregation objected to his pronouncement about public morals and discharged him from his pulpit, compelling him to become a missionary to Frontier Indians.

The passage that concludes the Personal Narrative hints at this difficulty and suggests some of Edwards' growing frustration about his isolation. It describes an episode of a Saturday night in January, 1739, about a year before Edwards began his memoir. It mentions, as earlier, 'sweetness' and the doctrine of God's Majesty and man's need for obedience. The pertinent part follows these notices, and voices Edwards' reaction. He says, that as he considered 'the way of duty,' he broke forth into 'a kind of loud weeping.' He continues:

I was forced [in response] to shut myself up, and fasten the doors. I could not but, as it were, cry out, 'How happy are they which do that which is right in the sight of God! They are blessed indeed, they are the happy ones.' I had, at the same time, a very affecting sense how meet and suitable it was that God should govern the world, and order all things according to His own pleasure and I rejoiced in it, that God reigned, and that His will was done. (71-2)

I note here the contrast between joy and the world, the need to have joy apart from the world. Joy required privacy, but that privacy, more curiously, does not bring him one of those visions of Christ which he noted were numerous since 1737 and which might overwhelm his 'affections,' leading to tears. What Edwards has left, it seems, is right doctrine with disciplined 'affections' in response. Simply put, there are too many empty hours which make him conscious that the experience of the logos is transcendental, just as he wished, and that the right doctrine of God's sovereignty might be a poor substitute for the experience of Christ as the logos. Thus, as he now begins his weeping on this occasion, 'weeping' may be read as a sign of incipient hysteria, showing all the poignancy of a man suffering an anxiety attack on a lonely Saturday night. He evidently realized that in asserting the transcendent existence and force of the logos, any trivial moment of ordinary experience could only make him conscious of the price he had paid - that he had traded that early freshness of 'delight' which he distrusted for the recent security of right doctrine. Here, then, was the impetus for the Personal Narrative: Edwards would fashion patterns and strategies of a memoir that would smooth over this awareness of the anxiety of aging and the loss of 'delight.' First, he had depicted his awareness of the orthodox cycle to show that right doctrine validated his personal 'turn of heart.' But as this 
conversion did not assure him of the supernaturalism of grace, except for the 'alteration' of nature in the thunderstorm scene, he depicted a second which showed that grace is supernatural because it is an immediate concurrence of the heart to the reading of the logos. The first conversion, in retrospect, presented the cycle of grace chronologically in phenomenal experience, and the second conversion, ending in visions, was clearly a totally supernatural experience, enclosing the 'turn of heart,' the logos, and right doctrine within one transcendent event. Thus, the more Edwards grew in spirit, the more he could be assured of both his visions and his doctrine of God's Majesty, and their interchangeability. And thus, as Edwards comes to the disturbing last entry of the Narrative, he is well fortified for his anxiety. He can, once again, prepare himself for it by looking back to the first two conversions, and thereby reactivate and reexperience his own words - words that assure him his spirit is deepening in the way God ordained, even as his 'affection' of emotional 'delight' was waning and cutting him off from the world of ordinary experience.

\section{JOHN STEPHEN MARTIN}

The University of Calgary

Notes

1 Standard historical accounts of the 'Great Awakening' are: Alan Heimert, Religion and the American Mind: From the Great Awakening to the Revolution (Cambridge, Mass.: Harvard Univ. Press, 1966); Edwin Gaustad, The Great Awakening in New England (Chicago: Quardrangle Books, 1968); and Cedric B. Cowing, The Great Awakening and the American Revolution: Colonial Thought in the 18th Century (Chicago: Rand McNally, 1971).

2 The classic exposition is Joseph Haroutunian's Piety Versus Moralism: The Passing of the New England Theology (New York and Evanston: Harper \& Row, 1932, 1970). Late-eighteenth-century developments are succinctly presented in Conrad Cherry, 'Nature and the Republic: The New England Theology,' New England Quarterly, 51:4 (December 1978), 509-26. See also studies in footnote 1. The 'Covenant' theology of New England demystified God's relations with mankind, giving church leaders the role of rational interpreters.

3 The challenges of the Antinomians and Arminians are critical to the rise of the Great Awakening; see footnote 1 and David Harlan, The Clergy and the Great Awakening in New England (Ann Arbor: UMI Research Press, 1980). The Arminian view meant that men could choose 'righteously' and thereby compel God to give them grace, or 'regeneration.' 
4 Henry F. May, The Enlightenment in America (New York: Oxford University Press, 1976), pp. 49-50, explores the paradoxes of Edwards' ideas and life.

5 Perry Miller, ed., 'Introduction,' Images or Shadows of Divine Things (New Haven: Yale University Press, 1948), pp. 1-41.

6 Vincent Tomas, 'The Modernity of Jonathan Edwards,' New England Quarterly, 25:1 (March, 1952), 60-84; Peter Gay, A Loss of Mastery: Puritan Historians in Colonial America (Berkeley and Los Angeles: University of California Press, 1966), pp. 88-117. Specifically, Gay argues that for Edwards 'history' is a 'calculus' of mystery and myth which proves the accuracy of the Bible, and in no way is history a study of the past in the manner of the eighteenth-century philosophes.

7 See Norman Fiering, Jonathan Edwards's Moral Thought and Its British Context (Chapel Hill: University of North Carolina, 1981).

8 'Editor's Introduction,' Scientific and Philosophical Writings, ed. Wallace E. Anderson, vol. 6, The Works of Jonathan Edwards (New Haven and London: Yale University Press, 1980), pp. 1-52.

9 Terence Erdt, 'The Calvinist Psychology of the Heart and the 'Sense'of Jonathan Edwards,' Early American Literature, 13:2 (Fall, 1978), 165-80, notes that Edwards' concept of the 'sense of the heart' - which Perry Miller saw as Edwards' extension of Locke's ideas - was not innovative but an application from several sources, chiefly traditional New England Calvinism, especially from the thought of William Ames and Thomas Hooker; it marks the limits of the 'covenant' theology's rationalism.

10 The model for the action of grace upon the individual in seventeenth-century New England is cogently explained in Edmund S. Morgan, Visible Saints: The History of a Puritan Idea (New York: New York University Press, 1963).

11 Edwards' debt to Locke and his individual interpretation of the 'new science' are treated in two classic studies by Perry Miller: 'Jonathan Edwards and the Great Awakening' and 'The Rhetoric of Sensation,' reprinted in Errand Into the Wilderness (New York: Harper Torchbook, 1956, 1964), pp. 153-66 and 167-83. The entire provenance of Locke (and Newton) in Edwards' scientific and philosophical thought is more recently treated in Wallace E. Anderson, 'Editor's Introduction,' op. cit., pp. 52-136; similarly useful for understanding Edwards' use of Locke in defining the 'freedom of the will' and the process of grace is the 'Editor's Introduction,' Freedom of the Will, ed. Paul Ramsey, vol. 1, The Works of Jonathan Edwards (New Haven and London: Yale University Press, 1957), pp. 47-65.

12 Freedom of the Will, op. cit., p. 321: 'But if there be any acts which are done in a state of equilibrium or spring immediately from perfect indifference and coldness of heart, they cannot arise from any good principle or disposition in the heart .... To have a virtuous heart, is to have a heart that favors virtue, and is friendly to it, and not one perfectly cold and indifferent about it'. Hence 'moral responsibility' seems to be a choice of the faculty of the understanding.

13 Paul Ramsey, Freedom of the Will, op. cit., pp. 47-65, notes how Edwards, unlike Locke, argued that the will was not 'at rest' until forced to make a choice, but was 'disposed' to see in experience what might be a 'good'; this is a novel sub- 
jective view that conjoins freedom and necessity. The aspect of 'instantaneous change' of a man's nature is exemplified in the thought of extreme pietists who had Antinomian tendencies; see Experience Mayhew, Grace Defended, In a Modest Plea for an Important Truth... (Boston, 1744) as reprinted in Richard Bushman, The Great Awakening: Documents on the Revival of Religion (New York: Antheneum, 1970), p. 142. Edwards' view of the 'disposition' is similar to that of the pietists, but is actually a sign of Edwards' fear that men might mistake emotional euphoria for the experience of grace, and then after discovering their error, be subject to bitter despair; such a misapprehension, Edwards wrote, caused the suicide of his Uncle Hawley in June, 1735; see his 'Narrative of Surprising Conversions,' in Jonathan Edwards: Representative Selections ..., ed. Clarence H. Faust and Thomas H. Johnson (New York: Hill and Wang, 1962), pp. 83-4.

14 Indeed, Emerson is an Idealist of Bishop Berkeley's persuasion. See Edwards' The Mind,' Scientific and Philosophical Writings, op. cit., p. 357: 'The supposition of God which we speak of is nothing else but God's acting in the course and series of his exciting ideas as if they, the things supposed, were in [sic] actual idea.'

15 David Laurence, 'Jonathan Edwards, John Locke, and the Canon of Experience,' Early American Literature, 15:2 (Fall, 1980), 107-23, stresses Edwards' major differences from Locke and harmonizes Edwards' 'new sense' with traditional 'covenant' Calvinism; the generation of spiritual knowledge, when 'the new sense' encounters Scripture, is similar to Thomas Shepard's process of 'regeneration.'

16 Thomas Shepard, The Autobiography, in God's Plot: The Paradoxes of Puritan Piety, Being the Autobiography and Journal of Thomas Shepard, ed. Michael McGiffert (Amherst: University of Massachusetts Press, 1972), p. 41. Henceforth, all references to Shepard's Autobiography will be given parenthetically.

17 Jonathan Edwards (Cleveland and New York: Meridian Books, 1959), pp. 146-7: My point is that whatever it owed to impulse, it was also conscious design.'

18 'According to an eyewitness, one of Edwards' fellow ministers, 'there was such a breathing of distress, and weeping, that the preacher was obliged to speak to the people and desire silence, that he might be heard.' This account is cited in Alfred Owen Aldridge, Jonathan Edwards (New York: Washington Square Press, 1964), p. 30. Edward H. Davidson, Jonathan Edwards: The Narrative of a Puritan Mind (Boston: Houghton Mifflin Co., 1966), p. 79: 'Yet the terror came not from Edwards' voice and gestures: we know that he stood fixedly in the pulpit of the Enfield church, set his eyes on the bellrope at the rear, and spoke the words in a level tone and with no high pomp of rhetoric or oratory. The feelings he aroused in his audience were not of his making; indeed, he several times admonished his listeners to stop groaning and crying aloud and to be still.'

19 Perry Miller, Images or Shadows of Divine Things (New Haven: Yale University Press, 1948); Miller, Jonathan Edwards, p. 186: Edwards 'said, as flatly as any Calvinist could wish, that a gracious emotion comes from a supernatural influence, but he then offered such a description of the operation of the supernatural as was, and remains ..., highly naturalistic ....'

20 Paul David Johnson, 'Jonathan Edwards' 'Sweet Conjunction,' Early American Literature, 16:3 (Winter 1981/82), 270-81. Daniel B. Shea, The Art and Instruction of Jonathan Edwards's Personal Narrative,' reprinted in William J. Scheick, Critical Essays on Jonathan Edwards (Boston: G.K. Hall \& Co., 1980), p. 270: 
'common grace ... assisted natural principles by removing prejudices and illuminating the truth of ... doctrine'; and p. 272: 'Edwards dramatizes a new kind of perception and so involves divine attributes with natural phenomena that abstraction is made vivid and concrete.'

21 Jonathan Edwards: Representative Selections ..., pp. 60-1. Henceforth all references to this source will be given parenthetically in the text.

22 Terence Erdt, op. cit., finds that Edwards' key words of 'heart,' 'sweetness,' and 'excellency' are found in the standard lexicon of Calvinist piety, not in the sensationalism of Locke.

23 Paul David Johnson's conclusion about 'sweet conjunction' ends with an 'experience of the consciousness of God,' but neglects to explain the theological significance of this 'consciousness.' Instead, speaking of the thunderstorm scene, Johnson writes of its aesthetic impact: 'This is Edwards' sweet conjunction: the conjunction of inward and outward sky in song. Edwards' singing sings the skies, and the skies sing Edwards. To experience such a world is to renew the very appetite for life itself. To linger in Edwards' Narrative is to taste the sweetness of that song' (op. cit., 279).

24 Perhaps R.C. DeProspo, 'The'New Simple Idea'of Edwards' Personal Narrative,' Early American Literature, 14:3 (Fall, 1979), 200-201, comes closest in noting how incantation generates a suggested meaning that does not depend on diction or figurative language. Referring to the thunderstorm scene, DeProspo writes: 'This kind of contemplation ... aspires, through the stylization of incantation and song, somewhat to transcend the natural roots of language itself. To chant words is to attempt the articulation of a significance that transcends the explicit meaning of words.' 